\title{
Crustal structure across the post-spreading magmatic ridge of the East Sub-basin in the South China Sea: Tectonic significance
}

\author{
He Enyuan ${ }^{1,3}$, Zhao Minghui ${ }^{1,{ }^{*}}$, Qiu Xuelin ${ }^{1}$, Sibuet Jean-Claude ${ }^{2}$, Wang Jian ${ }^{1,3}$, Zhang Jiazheng ${ }^{1}$ \\ ${ }^{1}$ Key Laboratory of Marginal Sea Geology, South China Sea Institute of Oceanology, Chinese Academy \\ of Sciences, Guangzhou 510301, China \\ ${ }^{2}$ Ifremer Centre de Brest, 29280 Plouzané, France and 44 rue du Cloitre, 29280 Plouzané, France \\ ${ }^{3}$ University of Chinese Academy of Sciences, Beijing 100049, China \\ *Corresponding author : Minghui Zhao, email address : $\underline{\text { mhzhao@scsio.ac.cn }}$
}

\begin{abstract}
:
The $140-\mathrm{km}$ wide last phase of opening of the South China Sea (SCS) corresponds to a $\mathrm{N} 145^{\circ}$ direction of spreading with rift features identified on swath bathymetric data trending N055 (Sibuet et al., 2016).

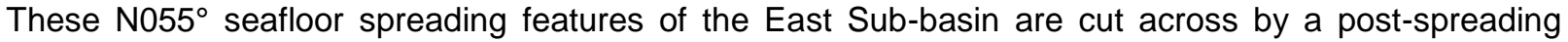
volcanic ridge oriented approximately $\mathrm{E}-\mathrm{W}$ in its western part (Zhenbei-Huangyan seamounts chain). The knowledge of the deep crustal structure beneath this volcanic ridge is essential to elucidate not only the formation and tectonic evolution of the SCS, but also the mechanism of emplacement of the postspreading magmatism. We use air-gun shots recorded by ocean bottom seismometers to image the deep crustal structure along the N-S oriented G8G0 seismic profile, which is perpendicular to the Zhenbei-Huangyan seamounts chain but located in between the Zhenbei and Huangyan seamounts, where topographic changes are minimum. The velocity structure presents obvious lateral variations. The crust north and south of the Zhenbei-Huangyan seamounts chain is ca. 4-6 km in thickness and velocities are largely comparable with those of normal oceanic crust of Atlantic type. To the south, the Jixiang seamount with a $7.2-\mathrm{km}$ thick crust, seems to be a tiny post-spreading volcanic seamount intruded along the former extinct spreading ridge axis. In the central part, a $1.5-\mathrm{km}$ thick low velocity zone $(3.3-3.7 \mathrm{~km} / \mathrm{s})$ in the uppermost crust is explained by the presence of extrusive rocks intercalated with thin sedimentary layers as those drilled at IODP Site U1431. Both the Jixiang seamount and the Zhenbei-Huangyan seamounts chain started to form by the intrusion of decompressive melt resulting from the N-S post-spreading phase of extension and intruded through the already formed oceanic crust. The Jixiang seamount probably formed before the emplacement of the E-W post-spreading seamounts chain.
\end{abstract}




\section{Highlights}

- The 2D velocity structure along a profile perpendicular to the Zhenbei-Huangyan seamounts chain corresponds to oceanic crust affected by post-spreading magmatism. The low velocity body (3.3-3.7 $\mathrm{km} / \mathrm{s}$ ) located in the uppermost crust might correspond to extrusive rocks intercalated with thin sedimentary layers. The Jixiang seamount with thicked crust $(7.2 \mathrm{~km})$, a tiny post-spreading volcanic seamount, maybe formed by the buoyancy-driven upwelling mechanism.

Keywords : East Sub-basin of the South China Sea, Zhenbei-Huangyan seamounts chain, 2-D crustal structure, post-spreading magmatism

\section{Introduction}

The South China Sea (SCS), a western Pacific marginal sea, is located among the Eurasian, Philippine Sea and Indo-Australian plates (Fig. 1a). Based on bathymetric and tectonic characteristics, the SCS is divided into three Sub-basins, namely the East, Southwest and Northwest Sub-basins (Fig. 1b) (Briais et al., 1993; Yao, 1996). In the East Sub-basin, uncertainties still exist concerning the cessation of seafloor spreading activity either at $\sim 15.5 \mathrm{Ma}$ (Taylor and Hayes, 1980, 1983; Briais et al., 1993; Sun et al., 2009; Li et al., 2014) or at $20.5 \mathrm{Ma}$ (Barckhausen et al, 2014). After the cessation of seafloor spreading activity, the post-spreading volcanic ridge (PSVR) was built partly along the extinct spreading ridge (ESR) oriented ${\mathrm{N} 055^{\circ}}^{\circ}$ in the eastern part of the East Sub-basin and partly across the ESR (E-W Zhenbei-Huangyan 
seamounts chain) in the western part of the East Sub-basin (Wang et al., 1984; Tu et al., 1992; Briais et al., 1993; Wang et al., 2009; Sibuet et al., 2016). Compared with the Hawaiian-Emperor seamounts chain produced by mantle plume activities (Morgan, 1972), the Zhenbei-Huangyan seamounts chain does not show obviously along-trend variation with age. Therefore, these seamounts chains are likely to have different mechanisms of formation, particularly in terms of their magma sources. Where do the magma source derived from to build the seamounts in the SCS and how do the magmatic activities affect the pre-existing oceanic crust?

Due to the geographic remoteness and large bathymetric depth of the East Sub-basin, the origin of the PSVR is largely unknown. A three-dimensional (3D) ocean bottom seismometer (OBS) seismic survey was carried out along a small E-W portion of the PVSR, in the area of the Zhenbei and Huangyan seamounts in May 2011 (Zhang et al., 2013). The 3D seismic structure is already published (Wang et al., 2016). In this paper, we focus on the N-S G8G0 profile, which is almost perpendicular to the PVSR and located between the two Zhenbei and Huangyan seamounts, where the topography is reduced. The obtained velocity and density structures will be used to unravel the mechanism of the post-spreading magmatic emplacement.

\section{Tectonic setting}

The SCS marginal sea is located at the confluence of three major plates (Eurasian, Philippine Sea and Indian-Australian plates) (Fig. 1a). The East Sub-basin, the largest basin among the three SCS Sub-basins, is the major constituent of the SCS. The abyssal plain in the East Sub-basin lies in between 4300 and $4500 \mathrm{~m}$ deep. East of the Zhongnan faults zone, which separates the East and Southwest Sub-basins, the Zhenbei-Huangyan seamounts chain is trending E-W over a distance of $240 \mathrm{~km}$ and consists of five major seamounts, which stand nearly $4000 \mathrm{~m}$ above the seafloor (Yao, 1996) (Figs. $1 \mathrm{~b}$ and 2). Its width is $\sim 40 \mathrm{~km}$. Further east, this chain changes direction to NE-SW over $100 \mathrm{~km}$ and disappears near the Manila trench.

Based on the original magnetic anomalies interpretation (Taylor and Hayes, 1980; Briais et al., 1993; Li et al., 2011), Li et al. (2014) re-identified and relocated the magnetic anomalies by using recent deep-tow magnetic surveys and IODP Expedition 349 results. They pointed out that the SCS seafloor spreading formed from Oligocene to Early Miocene (33-15 Ma) (chrons 
C12-C5B) and the history of seafloor spreading was divided into two stages (Fig. 1b) (Li et al., 2014). The first stage (33-26 Ma) corresponds to chrons $\mathrm{C} 12$ to $\mathrm{C} 8$ and is associated with a NNW-SSE seafloor spreading direction with $\sim$ E-W and ENE-WSW trending magnetic lineations developed in the East and Northwest Sub-basins. The second stage (26-15 Ma) corresponds to chrons $\mathrm{C} 8$ to $\mathrm{C} 5 \mathrm{~B}$ and continues along a NNW-SSE seafloor spreading direction until chron C6Cr $(\sim 23.6 \mathrm{Ma})$, where the ridge jumped $\sim 20 \mathrm{~km}$ southward and then rapidly propagated to the southwest. Subsequently, the Southwest Sub-basin opened and the ridge orientation of the East Sub-basin varies from ENE-WSW to NE-SW. The terminal age of seafloor spreading is about 15 Ma in the East Sub-basin and 16 Ma in the Southwest Sub-basin, corresponding to anomalies C5B for Li et al. (2014) and post-C5c for Briais et al. (1993), respectively.

However, Barckhausen et al. (2014), using a series of magnetic profiles where careful magnetic corrections were applied, modeled magnetic lineations by maintaining spreading rates constant over long periods of time and found that seafloor spreading ended at the same time (chron C6a1, 20.5 Ma) in the East and Southwest Sub-basins. The main divergent point between the three modelings is the age of the youngest identified magnetic lineations (younger than C5c (Briais et al., 1993), C5B (Li et al., 2014) and C6a1 (Barckhausen et al., 2014)). One of the reasons of this large discrepancy is the presence of a strong post-spreading volcanism (ca. 8-13 Ma) (Expedition 349 Scientists, 2014), which hides the previous spreading fabric in particular in the region of the extinct spreading axis and thus complicates the identification of magnetic lineations.

In the past, two sets of basement faults were recognized in the East Sub-basin, including NE-SW and a NW-SE trending sets (Pautot et al., 1986, 1990; Briais et al., 1993; Li et al., 2002, 2011). The NE-SW features, acting as magma conduits, were considered as due to a significant and long-lasting control on the orientation of the post-spreading seamounts chain, mostly west of the Manila trench (Pautot et al., 1986, 1990; Li et al., 2011). The NE-SW trending features, symmetrically distributed on both sides of the ESR, are almost parallel to the direction of magnetic anomalies, and were considered as seafloor spreading features with a significant control on the regional tectonics (Pautot et al., 1986, 1990; Li et al., 2002, 2011). However, NW-SE trending features, with a dominant strike oriented $\mathrm{N} 137^{\circ}$ (Li et al., 2002), were considered as transform faults not re-used during the post-spreading magmatic activity. 
After the cessation of seafloor spreading, magmatic activities continued and the East Sub-basin axial area was overprinted by the Zhenbei and Huangyan seamounts, which are dated 7.7 and 9.9 Ma from dredged volcanic samples (Wang et al., 1984; Wang et al., 2009). The volcano-clastic breccias and sandstone at IODP Site U1431 are dated at 13-8 Ma, indicating that extensive seamount volcanic activity restarted $\sim 2 \mathrm{Myr}$ or $\sim 7.5 \mathrm{Myr}$ after the cessation of seafloor spreading (Expedition 349 Scientists, 2014, Barckhausen et al., 2014 respectively) and lasted for at least 5 Myr.

Fig. 1 shows the location of the ESR slightly modified from Sibuet et al. (2016), who delimited oceanic domains based on swath bathymetric data and magnetic lineations. East of $118^{\circ} 15^{\prime} \mathrm{E}$, the PSVR follows the $\mathrm{N} 055^{\circ}$ trends of the last phase of opening of the East Sub-basin bounded by the two red dashed lines in Fig. 1. West of $118^{\circ} 15^{\prime} \mathrm{E}$, the PSVR departs from the $\mathrm{N} 055^{\circ}$ trending direction and is approximately E-W oriented, though minor post-spreading volcanoes might be $\mathrm{N} 055^{\circ}$ trending (e. g. Jixiang seamount and the unnamed seamount east of it in Fig. 2). A possible interpretation is that the $\sim \mathrm{N}-\mathrm{S}$ post-spreading extension resulting in the emplacement of the western part of the PSVR (Sibuet et al., 2016) first followed the previously formed $\mathrm{N} 055^{\circ}$ seafloor spreading lineations and then shifted to an E-W trend perpendicular to the extensional direction of the post-spreading phase of extension, cutting obliquely the already formed $\mathrm{N} 055^{\circ}$ seafloor spreading features. This means that the E-W portion of the PSVR is not the location of the ESR as assumed by Briais et al. (1993), Barckhausen et al. (2014) and Li et al. (2014).

\section{Seismic data acquisition and processing}

In May 2011, the $R / V$ Shiyan 2 (South China Sea Institute of Oceanology, Zhang et al., 2013) ran a deep seismic survey in the East Sub-basin. Nine broad band (0.01-50 Hz) OBSs built in China (Hao and You, 2011) were deployed along a 110-km-long N-S profile (G8G0), located in between the Zhenbei and Huangyan seamounts and cutting across the ESR of East Sub-basin in the southern part of the profile (Fig. 2). The sampling rate was set up at $125 \mathrm{~Hz}$ during the survey. The seismic source consisted of a four-air-gun array with a total volume of $6000 \mathrm{in}^{3}$ towed at a 10-m depth below sea level. The shooting interval was $120 \mathrm{~s}$ and the nominal speed of the ship 
was 5 knots. 448 shots were fired along the G8G0 profile from south to north (Fig. 2). Even if it is of low quality, a single channel reflection seismic profile was simultaneously acquired. Detailed shooting and deploying parameters appear in Zhang et al. (2013).

The processing of OBS data takes into account the OBS time drift and includes the correction of shot and OBS positions. Firstly, we adjusted the shot positions using the Global Positioning System (GPS) of the ship moved to the center of the air-gun array (Ao et al., 2010). Secondly, the OBSs clocks offset were checked before and after deployments, and a linear drift was assumed during the launching period. The recorded OBS data were then converted into the standard format of the Society of Exploration Geophysicist (SEGY) and stored in common receiver gathers. Thirdly, the OBS instruments were relocated on the seafloor by inverting the direct water-wave travel times (Monte Carlo and least square methods (Ao et al., 2010; Zhang et al., 2011). Globally, OBS data are of good quality with seismic signals recorded down to the Moho interface. Seismic record sections were plotted for each OBS with a reduced velocity of $6.0 \mathrm{~km} / \mathrm{s}$ and with a $3-12 \mathrm{~Hz}$ band-pass filter (Figs. 3a to 6a and Figs. A.1b to 5b).

\section{Seismic velocity structure}

\subsection{Characteristics of seismic phases}

Most of the OBS data acquired along the profile G8G0 are of high quality, with numerous seismic phases traced at large offsets (Figs. $3 b$ to $6 \mathrm{~b}$ and Figs. A.1b to 5b). Seismic phases Pw, Pg1, Pg2, PmP and Pn are identified according to their kinematic and dynamic characteristics. The direct water-wave phase Pw (red) is used to relocate the OBSs positions (Zhang et al., 2013). Seismic phases $\operatorname{Pg} 1$ (green) and Pg2 (blue) are refracted from oceanic layers 2 and 3, respectively. They can be traced continuously within offset ranges from 5 to $30 \mathrm{~km}$. The hyperbolic PmP phases (yellow), reflected from the crust-mantle interface, are usually recorded at short offsets due to the possible scattering caused by the rough seafloor relief or to crustal velocity gradients. Pn phases (pink) refracted from the upper mantle are clear and usually displayed at long offsets. Four OBS records are taken as examples and analyzed in detail.

OBS02 is located in the northern part of the profile at a depth of $4280 \mathrm{~m}$ (Fig. 2). On the seismic record section (Fig. 3a), Pg phases (green and blue) are clearly seen within the -30 to 20 
$\mathrm{km}$ offset. The PmP phase (yellow) appears within the -24 to $-19 \mathrm{~km}$ offset and 15 to $20 \mathrm{~km}$ offset on both sides of receiver OBS02, respectively. The short PmP offsets imply that the crust is thin. Pn phases (pink) are observed at the offset of -88 to $-34 \mathrm{~km}$ with an apparent velocity of $8.0 \mathrm{~km} / \mathrm{s}$. The upward shape at the offset of -78 to $-68 \mathrm{~km}$ is due to the presence of the Jixiang seamount (Fig. 3).

OBS05 and OBS06 are located at depths of 4070 and $4270 \mathrm{~m}$, between the Zhenbei and Huangyan seamounts (Fig. 2). A set of seismic phases Pg, PmP and Pn, is clearly visible on both branches of OBS05 (Fig. 4a). The Pg phases (green and blue) appear within the -24 to $24 \mathrm{~km}$ offset. The Pn phases (pink) can be followed continuously on both sides of OBS05 within the -24 to $-56 \mathrm{~km}$ offset and the 24 to $50 \mathrm{~km}$ offset. The PmP phase (yellow), clearly followed beneath the Pg arrivals with obviously hyperbolic curves, is crucial for determining the Moho interface below the seamounts chain. PmP arrivals appear from -20 to $-9 \mathrm{~km}$ offset on the left half branch and 17 to $25 \mathrm{~km}$ offset on the right half branch. The characters of seismic phases of OBS06 (Fig. 5a) are similar to those of OBS05 (Fig. 4a). As on the OBS02 record, the Pn (pink) phases at the offset of -45 to $-36 \mathrm{~km}$ on OBS05 (Fig. 4) and at the offset of -34 to $-25 \mathrm{~km}$ on OBS06 (Fig. 5) are also affected by the presence of the Jixiang seamount (Fig. 3).

OBS09, at a water depth of $4280 \mathrm{~m}$, is the southernmost OBS of Profile G8G0 (Fig. 2). The Jixiang seamount is located near OBS09. The Pg1 phase (green) has upward shape in the range of 4 to $12 \mathrm{~km}$ offset (Fig. 6a), which could be due to lateral velocity heterogeneities linked to volcanic activities. The most noticeable phase Pn (pink) can be traced continuously from 22 to 98 $\mathrm{km}$ offset. At offset of 75 to $98 \mathrm{~km}$, the Pn phase (pink) appears with a 'stair-step' shape. This pattern is also observed on other records, such as the 5 to $20 \mathrm{~km}$ offset for OBS02 (Fig. 3a), at 30 to $54 \mathrm{~km}$ offset for OBS05 (Fig. 4a), and at 15 to $30 \mathrm{~km}$ offset for OBS03 (Fig. A.3a). Considering the flat seafloor relief given by the swath-bathymetric data (Fig. 2), these stepwise travel times (Figs. 3a to $6 \mathrm{a}$ and Figs. A.3a) may have been caused by the basement change located at a distance of 95 to $110 \mathrm{~km}$ on the single channel seismic reflection (Fig. 7a).

\subsection{Modeling approach and reliability analysis}

The 2-D velocity-depth models (Fig. 8) are obtained by using the 2-D forward ray-tracing RayInvr software (Zelt and Smith, 1992) and then the TOMO2D joint refraction and reflection 
travel time inversion code of Korenaga et al. (2000).

Firstly, we establish the initial model for RayInvr based on the single channel seismic profile (Fig. 7a), the seismic phases of the nine OBSs, located along the profile G8G0, and regional geological and geophysical data (Yao and Wang, 1983; Liu, 2000; Li et al., 2015). The model consists of five layers: seawater, sediments, upper crust (oceanic layer 2), lower crust (oceanic layer 3) and upper mantle, corresponding to velocities of $1.5 \mathrm{~km} / \mathrm{s}, 1.7$ to $2.6 \mathrm{~km} / \mathrm{s}, 4.5$ to $6.4 \mathrm{~km} / \mathrm{s}$, 6.4 to $7.0 \mathrm{~km} / \mathrm{s}$ and 8.0 to $8.2 \mathrm{~km} / \mathrm{s}$, respectively.

Seismic sequence boundaries for the sediment layer were mapped on the G8G0 single channel seismic profile, according to stratigraphic correlations between MCS profiles 973SCSIO1 and SO49-17 (located in Fig. 1b) and coring/logging data from IODP Site U1431 (Fig. 7a) (Li et al., 2015). Tmm, Tmp and Tpp are middle Miocene/late Miocene, Miocene/Pliocene, and Pliocene/Pleistocene boundaries, respectively ( $\mathrm{Li}$ et al., 2015). The seismic facies and sequence boundaries are easily traced because of their distinct seismic characteristics. For example, the Pliocene sedimentary layer displays a weak seismic reflectivity, compared to the strong seismic reflectivities of the Pleistocene sequence above and the Miocene sequence below. The intensity grades of seismic facies show the different lithologies, which are confirmed by the coring/logging data at Site U1431 (Li et al., 2014; 2015). The velocity and thickness of the sediments are based on the quadratic time-depth conversion function $\mathrm{z}$ in meters where $z=0.000188295 t^{2}+0.695896$ $t$ with $t$ in ms is the two-way travel time (TWTT) (Li et al., 2015). The $6.4 \mathrm{~km} / \mathrm{s}$ velocity contour generally coincides with the boundary between layer 2 and 3 (Harding et al., 1993).

For the forward modeling (Fig. 8a), the initial model was continuously adjusted to fit the observed and theoretical travel times by using the trial and error method (Zelt and Smith, 1992). The inverted velocity model (Fig. 8a) and the sediment layer are a priori information used each time in the next inversion step. Travel times of Pg1, Pg2, PmP and Pn phases are used to obtain the crustal velocity distribution and the Moho geometry. The travel time residuals numbers of picks and normalized $\chi^{2}$ values for each seismic phase are summarized in Table 1 . Travel time uncertainties are estimated at $50 \mathrm{~ms}, 70 \mathrm{~ms}$ and $90 \mathrm{~ms}$ for $\mathrm{Pg}, \mathrm{PmP}$ and $\mathrm{Pn}$ arrivals, respectively, depending on the quality of travel time picks. The total root-mean-square (RMS) travel time residuals is $0.076 \mathrm{~s}$ for the final velocity model, and normalized $\chi^{2}$ is 1.262 (Table 1 ), which is close to the optimal value of 1 . In general, the coverage of ray paths is more than 10 to 20 hits, 
reaching 30 to 40 hits amongst OBSs, even over 60 hits in some areas (Fig. 8b), which indicates a high reliability for the final model. The uncertainties in velocity and Moho depth were defined by using the F-test referenced by Zelt (1999) and Niu et al., (2015). The result (Table A.1) indicates that the uncertainties in crustal velocity are less than $0.4 \mathrm{~km} / \mathrm{s}$ and the uncertainty in Moho depth is $\pm 0.36 \mathrm{~km}$.

Secondly, we use the TOMO2D joint refraction and reflection travel time inversion code (Korenaga et al., 2000) for modeling. The Korenaga tomographic approach provides a smooth velocity model mostly constrained by the refracted phases. Compared to the Zelt and Smith (1992) approach, this technique requires much less a priori information and prevents from over-interpretating the data. It is actually a joint refraction and reflection travel time tomography method. Refracted phases (first arrivals) and reflections at the base of the crust (PmP) are inverted simultaneously to provide a one-layer, continuously varying velocity model and a floating reflector representing the base of the crust. Note that the reflector at the base of the crust is not correlated to any velocity jump: it is not stricto sensu the Moho interface. A starting velocity model is required by the tomographic approach. The shallower part of this model is built using the geometry and velocity of the sedimentary layers inferred from the seismic reflection profile (Fig. 7a). Below the basement, the velocity is uniformly set up at $4.5 \mathrm{~km} / \mathrm{s}$ and $8.2 \mathrm{~km} / \mathrm{s}$ from the top to the bottom and a vertical gradient is added. The starting floating Moho reflector is introduced at a constant depth of $11 \mathrm{~km}$.

We tried to get a solution with the least amount of required structure that fits the observed travel times adequately (low RMS and $\chi^{2}$ ideally close to 1 ) in the least number of iterations. Both the refraction and reflection travel times constrain the velocities. Our grid spacing is $\Delta x=250 \mathrm{~m}$ and $\Delta \mathrm{z}=125 \mathrm{~m}$ immediately below the seafloor to $16 \mathrm{~km}$ at the bottom of the model, and the smoothing correlation lengths are $2.0-4.0 \mathrm{~km}$ and $0.2-\mathrm{m} 2.0 \mathrm{~km}$ from top to bottom in the horizontal and vertical directions, respectively. After 10 iterations, we gained the final model (Fig. 9a) with a RMS residual of $80 \mathrm{~ms}$ and a normalized $\chi^{2}$ value of 1.63 . The uncertainties of velocities and Moho discontinuities (Fig. 9b) were calculated by Monte Carlo analysis (Korenaga et al., 2000). Thus, the uncertainties in crustal and upper mantle velocities are less than 0.1 and 0.3 $\mathrm{km} / \mathrm{s}$ (Fig. 9b), respectively. The uncertainty of the Moho depth is about $0.35 \mathrm{~km}$ beneath OBS02 and OBS03 and up to $0.9 \mathrm{~km}$ beneath OBS09. The derivative weight sum (DWS) is the 
column-sum vector of the velocity kernel and measures the ray coverage, which estimates ray density with a hit count that weights each ray by its distance to the model parameter. The DWS of the final velocity model is shown in Fig. 9c. White areas correspond to poorly constrained regions (DWS $<1.0$ ).

The two velocity structures of forward and tomographic modelings (Figs 8a and 9a) are very similar: same shape tendency of the $6.4 \mathrm{~km} / \mathrm{s}$ contour, same low velocity anomaly in the upper crust in the central part and same Moho uplift located between OBS06 and OBS07. However, the tomographic modeling suggests a significant Moho rise beneath the Jixiang seamount located between OBS08 and OBS09.

\section{Discussion}

\subsection{Modeling results and nature of crust}

The velocity model shows significant lateral variations along the G8G0 profile (Figs. 8a and 9a). According to the velocity structure, the model is divided into three parts: the southern part (0 to $38 \mathrm{~km}$ ) consists of oceanic crust possibly intruded by the post-spreading Jixiang seamount emplaced along the ESR, the central part (38 to $86 \mathrm{~km}$ ) is characterized by post-spreading volcanism emplaced through the previously formed oceanic crust, and the northern part (86 to 110 $\mathrm{km})$ consists of oceanic crust. When compared with the 0-127 Ma oceanic crust velocity bounds (White et al., 1992), 1-D velocity-depth curves extracted from the 2-D velocity model (Fig. 8a) at $\mathrm{D}=17 \mathrm{~km}, 52 \mathrm{~km}$ and $90 \mathrm{~km}$ along the G8G0 profile show that the crust is globally representative of oceanic crust though its thickness varies from 4 to $7.2 \mathrm{~km}$ (Fig. 10).

The northern part of the profile ( 86 to $110 \mathrm{~km}$ in Figs. $8 \mathrm{a}$ and $9 \mathrm{a}$ ) shows a typical oceanic crust with a relatively constant thickness of $5 \mathrm{~km}$ (White et al., 1992). The velocity rises from 4.3 to $4.5 \mathrm{~km} / \mathrm{s}$ at the top to 6.9 to $7.0 \mathrm{~km} / \mathrm{s}$ at the bottom of the crust. Here, the 1-D curve at D $=90$ km (Fig. 10) is similar to the 1-D model of the Labrador Sea (Delescluse et al., 2015), a marginal sea with a clearly recognized extinct spreading ridge; and it is also alike to the 1-D models of the Aegir ridge (Brandsdóttir et al., 2015) with a 4-5 km thickness, which is slightly less than the 5.5-6.5 km observed by Grevemeyer et al. (1997). All these 1-D models represent normal oceanic crust not affected by post-spreading magmatism. In the southern part (0 to $38 \mathrm{~km}$ in Figs. $8 \mathrm{a}$ and 9a), the crust beneath the Jixiang seamount is $\sim 7.2 \mathrm{~km}$ thick, with a velocity varying from 4.5 
$\mathrm{km} / \mathrm{s}$ at the top of igneous rocks to $7.0 \mathrm{~km} / \mathrm{s}$ at the bottom of gabbros. The rising basement and Moho beneath the Jinxiang seamount, where travel time curves rise steeply at their corresponding offsets in Figs. 3 to 5, could be induced by a post-spreading magmatic intrusion. The crust thickens to $7.2 \mathrm{~km}$ (at D = $17 \mathrm{~km}$ in Fig. 10) and near OBS07, the thickness of the crust is similar to what was found in the northern part of the profile and is consequently of oceanic nature. However, south of the Jixiang seamount, the profile is not long enough to characterize the nature of the crust.

In the central part of the profile ( 38 to $86 \mathrm{~km}$ in Figs. $8 \mathrm{a}$ and $9 \mathrm{a}$ ), a low velocity body ( 3.3 to $3.7 \mathrm{~km} / \mathrm{s}$ ) is observed in the uppermost crust and velocities are lower than those of the typical adjacent oceanic crusts (Figs. 8a, 9a and 10). On OBS seismic record sections, seismic phases are faint and blurred (Figs. 3a to 6a). This could be due to the presence of a series of small basement relieves evidenced on the single-channel seismic reflection profile (Fig. 7a). All these observations might indicate that, even if the post-spreading volcanic seamounts are globally E-W oriented, the weak zones of the former oceanic crust (rift or fracture zone trends) have been only used very locally during the emplacement of the post-spreading magmatic features within the central part of the profile. This is suggested by the morphology of the Zhenbei and Huangyan seamounts where both NE-SW and NW-SE trends are clearly expressed (Fig. 2) and it has been shown by the shape of the 3-D seismic tomography below the Zhenbei-Huangyan seamounts chain (Wang et al., 2016).

\subsection{Low velocity zone in the uppermost crust}

If the northern part of the profile is unaffected by post-spreading magmatism, however, in the central part, where is located the PSVR, the uppermost velocity is about $3.3-3.7 \mathrm{~km} / \mathrm{s}$. These values are much lower than those of the oceanic crust identified north and south of the central part (Figs $8 \mathrm{a}$ and 9a), in the surrounding oceanic regions (Table 2) and of the P-wave velocity of basaltic rocks sampled at IODP Site U1431 ( 5.0 km/s) (Li et al., 2015).

Defining the $4.5 \mathrm{~km} / \mathrm{s}$ as the normal velocity in the uppermost mature oceanic crust (Grevemeyer and Weigel, 1996), this low velocity zone is about $30 \mathrm{~km}$ wide and $1.5 \mathrm{~km}$ thick. Plausible causes for this anomalously low velocity values are: (1) A 9-m thick hemipelagic claystone was found between the two basaltic units at Site U1431 located near OBS3 when 


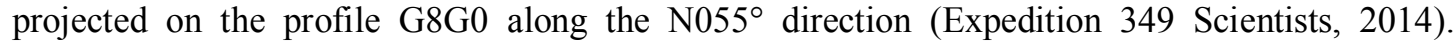
Several sills separated by such sedimentary layers might exist above the true oceanic crust (Sibuet et al., 2016), suggesting that the claystone occurrences may have reduced the mean velocities in the uppermost crust; (2) Both the rugged basement documented by the single-channel seismic reflection profile (Fig. 7) and the scatter seismic phases indicate that fractures may have developed in the vicinity of the PSVR (Figs. 4 to 7) contributing to the formation of the low velocity zone. We tend to favor the first hypothesis.

\subsection{Jixiang seamount}

The thickened crust $(7.2 \mathrm{~km})$ of the Jixiang seamount is markedly different of the typical oceanic crust (Figs. 8a, 9a and 10), which indicates the crust beneath the Jixiang seamount had been probably modified by the post-spreading magmatism. In the SCS, the post-spreading magmatism presents similar characteristics and similar tectonic environment with the ones of the Davidson seamount located above the fossil spreading center in the eastern Pacific (Castillo et al., 2010): (1) There is no evidence for the existence of a mantle plume or hot spot; (2) The seamounts share a common, heterogeneous mantle source (Tu et al., 1992; Wang et al., 2009; Perez et al., 2013); (3) The younger magma is characterized by a greater enrichment in incompatible trace elements (REE, LILE, HFSE) and radiogenic isotopes (Yan et al., 2008). Castillo et al. (2010) suggested that the post-spreading mechanism of formation of the Davidson seamount may be explained by the buoyancy-driven upwelling model, which may be applied to the case of the SCS East Sub-basin. The interpretation of the 3-D seismic tomography of the Zhenbei-Huangyan seamounts chain (Wang et al., 2016) also suggests a seamount formation mechanism similar to the one of the Davidson seamount. The residual melt trapped in the heterogeneous mantle after the cessation of seafloor spreading ascended upwards due to the buoyancy-driven decompression melting. Note that the formation mechanism of post-spreading seamounts in the East Sub-basin (Lin et al., 2013) is probably the same for the seamounts of the Southwest Sub-basin (Meng and Zhang, 2014) where high heat-flow values were recorded (Shi et al., 2003).

\subsection{Gravity model}

In order to obtain additional constraints and strengthen the reliability of the velocity structure 
(Fig. 8a), we have synthesized a forward density model by converting velocities to densities, and by comparing calculated and observed free-air gravity anomalies. Gravity data along the G8G0 profile (Fig. 11a) was extracted from the global 1'× 1' gravity grid (Sandwell et al., 2014). The seismic velocities $(V)$ were converted to the density model $(\rho)$ using the empirical relationships $\rho$ $=1.75+0.16 V$ for sediments (Nafe and Drake, 1963$) ; \rho=3.81-6.0 / V$ for layer 2 (Carlson and Herrick, 1990) and $\rho=0.375+0.375 \mathrm{~V}$ for layer 3 (Birch, 1960). The seawater and upper mantle were initially assumed to have a constant density of $1.03 \mathrm{~g} / \mathrm{cm}^{3}$ and $3.3 \mathrm{~g} / \mathrm{cm}^{3}$, respectively. We divided the model into several blocks, and then calculated the gravity anomaly value for each block before summarizing the values of all the blocks (Yao et al., 2003). The boundary effect was removed by extending the model domain $50 \mathrm{~km}$ outward on both sides of it. The fit between observed and calculated gravity values is reasonable $(\mathrm{RMS}=0.86 \mathrm{mGal})$.

14 different density blocks were used in the density model (Fig. 11b). The central part (38 to $70 \mathrm{~km})$ with low gravity values $(-10 \mathrm{mGal})$, displays low density crustal bodies $(2.30,2.65$ and $\left.2.80 \mathrm{~g} / \mathrm{cm}^{3}\right)$ compared with the external parts $\left(2.80\right.$ and $\left.2.90 \mathrm{~g} / \mathrm{cm}^{3}\right)$. The low density body $(2.30$ $\mathrm{g} / \mathrm{cm}^{3}$ ) corresponding to the low upper crustal velocities of $3.3-3.7 \mathrm{~km} / \mathrm{s}$, might correspond to highly porous clastic material, high-porosity pillow lavas or extrusive rocks with interstratified sedimentary layers as suggested by the above velocity analysis. In the southern part of the profile, the high gravity value $(20 \mathrm{mGal})$ associated with high-density bodies beneath the Jixiang seamount indicates that the nature of this seamount is different from the nature of seamounts located in the central part of the profile. This high-density body might correspond to a high-velocity intrusion.

\subsection{Geological model}

Combined with the interpretation of swath bathymetric data (Fig. 2), the wide-angle seismic reflection and refraction results obtained along the G8G0 profile allow to image not only the seafloor spreading fabric and the post-spreading magmatism of the East Sub-basin but also the deep structure of the underlying oceanic crust intruded by post-spreading magmatism. The proposed geological model (Fig. 12) is built along the G8G0 profile, perpendicularly to the E-W Zhenbei-Huangyan seamounts chain, and obliquely to the general trend of the Jixiang seamount. The red dashed line is the northern boundary of the spreading fabric of the central domain and the 
yellow line is the N055 ESR (Sibuet et al., 2016). Note that the Zhenbei seamount is emplaced along the $\mathrm{N} 055^{\circ}$ direction of spreading lineaments as also attested by the 3-D seismic tomography of the Zhenbei-Huangyan seamounts chain (Wang et al., 2016), even if the chain is E-W oriented. The red arrows show the upward motion of the residual melt due to the buoyancy-driven decompression melting after the cessation of seafloor spreading and resulting in the formation of both the Jixiang seamount and the PSVR. The Jixiang seamount, characterized by the intrusion of a high-density body (Fig. 11), possibly occurred during the early stage of the post-spreading magmatism, along a zone of weakness corresponding to the recently extinct spreading ridge (Fig. 2), which could be the result of an intrusion through a set of $N 055^{\circ}$ and conjugate $\mathrm{N} 145^{\circ}$ directions. Then, the Zhenbei-Huangyan seamounts chain was globally emplaced in an E-W direction but locally each seamount seemed to be emplaced along the $\mathrm{N} 055^{\circ}$ and $\mathrm{N} 145^{\circ}$ conjugate directions as shown by the swath-bathymetric data of Fig. 2 and the 3-D seismic tomography (Wang et al., 2016). Our study shows that Layer 2 is thick beneath the PSVR and displays a 1.5-km thick low velocity upper crustal layer, which may consist of extrusive basalts with intercalated sedimentary layers. Thus, it seems that, even if the early phase of emplacement of both the Jixiang seamount and the Zhenbei-Huangyan seamounts chain started with the same geodynamic processes, which consists to the rise of decompressive melt due to the N-S post-seafloor spreading extension, the Zhenbei-Huangyan seamounts chain with a E-W trend is in a more mature stage of emplacement with the later emplacement of extrusives intercalated with sedimentary layers.

\section{Conclusions}

The N-S oriented G8G0 wide-angle seismic reflection and refraction profile was shot perpendicularly to the post-spreading Zhenbei-Huangyan seamounts chain in between the Zhenbei and Huangyan seamounts, where the topographic variations are the weakest. The main results of this study are:

- The crust north and south of the Zhenbei-Huangyan seamounts chain is about 4-6 km thick and velocities are largely comparable with those of normal oceanic crust of Atlantic type.

- In the central part of the profile, the post-spreading volcanic ridge is characterized by a $6-\mathrm{km}$ 
thick crust with a velocity structure similar to the one of the adjacent oceanic crust. A $1.5-\mathrm{km}$ thick low velocity zone $(3.3-3.7 \mathrm{~km} / \mathrm{s})$ located in the uppermost crust is explained by the presence of extrusive rocks intercalated with thin sedimentary layers as drilled at IODP Site U1431.

- The Jixiang seamount, located south of the Zhenbei-Huangyan seamounts chain, seems to be a tiny post-spreading volcanic seamount intruded along the former seafloor spreading zones of weaknesses, probably before the emplacement of the E-W post-spreading Zhenbei-Huangyan seamounts chain. Both the Jixiang seamount and the Zhenbei-Huangyan seamounts chain initially formed by the intrusion of decompressive melt through the already existed oceanic crust resulting from the N-S post-spreading phase of extension.

\section{Acknowledgments}

We are grateful to the crew of the $R / V$ Shiyan 2 and scientists who took part in the scientific cruise. Insightful comments by Hongfeng Yang, Jian Lin and Yongjian Yao are kindly acknowledged. The GMT software (Wessel and Smith, 1995) was used in this study. This work is supported by the Chinese National Natural Science Foundation (contracts 91028002, 91428204, 41176053). The manuscript was improved by constructive reviews of Frauke Klingelhoefer and Xiongwei Niu.

\section{References}

Ao, W., Zhao, M.H., Qiu, X.L., Li, J.B., Chen, Y.S., Ruan, A.G., Li, S.J., Zhang, J.Z., Wu, Z.L., Niu, X.W., 2010. The correction of shot and OBS position in the 3D seismic experiment of the SW Indian Ocean Ridge. Chinese Journal of Geophys. 53, 2982-2991.

Ao, W., Zhao, M.H., Qiu, X.L., Ruan, A.G., Li, J.B., 2012. Crustal structure of the Northwest Sub-basin of the South China Sea and its tectonic implication. Earth Science-Journal of China University of Geosciences. 37, 779-790. doi: 10.3799/dqkx.2012.087. (in Chinese with English abstract).

Barckhausen, U., Engels, M., Franke, D., Ladage, S., Pubellier, M., 2014. Evolution of the South China Sea: Revised ages for breakup and seafloor spreading. Marine and Petroleum Geology. http://dx.doi.org/10.1016/j.marpetgeo.2014.02.022. 
Birch, F., 1960. The velocity of compressional waves in rocks to 10 kilobars: 1. Journal of Geophysical Research. 65, 1083-1102.

Briais, A., Patriat, P., Tapponnier, P., 1993. Updated interpretation of magnetic anomalies and seafloor spreading stages in the South China Sea: Implications for the Tertiary tectonics of Southeast Asia. Journal of Geophysical Research. 98, 6299-6328.

Brandsdóttir, B., Hooft, E.E., Mjelde, R., Murai, Y., 2015. Origin and evolution of the Kolbeinsey Ridge and Iceland Plateau, N-Atlantic. Geochemistry, Geophysics, Geosystems. 16, 612-634.

Carlson, R.L., 1998. Seismic velocities in the uppermost oceanic crust: Age dependence and the fate of layer 2A. Journal of Geophysical Research. 103, 7069-7077.

Carlson, R.L., Herrick, C.N., 1990. Densities and porosities in the oceanic crust and their variations with depth and age. Journal of Geophysical Research. 95, 9153-9170.

Castillo, P.R., Clague, D.A., Davis, A.S., Lonsdale, P.F., 2010. Petrogenesis of Davidson Seamount lavas and its implications for fossil spreading center and intraplate magmatism in the eastern Pacific. Geochemistry, Geophysics, Geosystems. 11, Q02005,doi:10.1029/2009GC002992.

Delescluse, M., Funck, T., Dehler, S.A., Louden, K.E., Watremez, L., 2015. The oceanic crustal structure at the extinct, slow to ultraslow Labrador Sea spreading center. Journal of Geophysical Research. 120, 5249-5272.

Expedition 349 Scientists. 2014. South China Sea tectonics: Opening of the South China Sea and its implications for southeast Asian tectonics, climates, and deep mantle process since the late Mesozoic. International Ocean Discovery Program Preliminary Report, 349 http://dx.doi.org/10.14379/iodp.pr.349.2014.

Grevemeyer, I., Weigel, W., 1996. Seismic velocities of the uppermost igneous crust versus age. Geophysical Journal International. 124, 631-635.

Grevemeyer, I., Weigel, W., Dehghani, G.A., Whitmarsh, R.B., Avedik, F., 1997. The Aegir Rift: Crustal structure of an extinct spreading axis. Marine Geophysical Researches. 19, 1-23.

Harding, A.J., Kent, G.M., Orcutt, J., 1993. A multichannel seismic investigation of upper crustal structure at $9^{\circ} \mathrm{N}$ on the East Pacific Rise: Implications for crustal accretion. Journal of Geophysical Research. 98, 13925-13944.

Korenaga, J., Holbrook, W.S., Kent, G.M., Kelemen, P.B., Detrick, R.S., Larsen, H.C., Hopper, 
J.R., Jensen, T.D., 2000. Crustal structure of the southeast Greenland margin from joint refraction and reflection seismic tomography, Journal of Geophysical Research, 105, 21591-21614.

Li, C.F., Li, J.B., Ding, W.W., Franke, D., Yao, Y.J., Shi, H.S., Pang, X., Cao, Y., Lin, J., Kulhanek, D.K., Walliams, T., Bao, R., Briais, A., Brown, E.A., Chen, Y.F., Clift, P.D., Colwell, F.S., Dadd, K.A., Hernández - Almeida, I., Huang, X.L., Hyun, S.M., Jiang, T., Koppers, A.A.P., Li, Q.Y., Liu, C.L., Liu, Q.S., Liu, Z.F., Nagai, R.H., Peleo - Alampay, A., Su, X., Sun, Z., Tejada, M.L.G., Trinh, H.S., Yeh, Y.C., Zhang, C.L., Zhang, F., Zhang, G.L., Zhao, X.X., 2015. Seismic stratigraphy of the central South China Sea basin and implications for neotectonics. Journal of Geophysical Research, 120, 1377-1399. doi: $10.1002 / 2014 J B 011686$.

Li, C.F., Xu, X., Lin, J., Sun, Z., Zhu, J., Yao, Y.J., Zhao, X.X., Liu, Q.S., Kulhanek, D.K., Wang, J., Song, T.R., Zhao, J.F., Qiu, N., Guan, Y.X., Zhou, Z.Y., Williams, T., Bao, R., Briais, A., Brown, E.A., Chen, Y.F., Clift, P.D., Colwell, F.S., Dadd, K.A., Ding, W.W., Almeida, I.H., Huang, X.L., Hyun, S.M., Jiang, T., Koppers, A.A.P., Li, Q.Y., Liu, C.L., Liu, Z.F., Nagai, R.H., Peleo - Alampay, A., Su, X., Tejada, M.L.G., Trinh, H.S., Yeh, Y.C., Zhang, C.L., Zhang, F., Zhang, G.L., 2014. Ages and magnetic structures of the South China Sea constrained by deep tow magnetic surveys and IODP Expedition 349. Geochemistry, Geophysics, Geosystems. 15, 4958-4983. doi:10.1002/2014GC005567.

Li, J.B., Ding, W.W., Gao, J.Y., Wu, Z.Y., Zhang, J., 2011. Cenozoic evolution model of the sea-floor spreading in South China Sea: New constraints from high resolution geophysical data. Chinese Journal of Geophys. 54, 3004-3015. doi:10.3969/j.issn.0001-5733.

Li, J.B., Jin, X.L., Gao, J.Y., 2002. Morpho-tectonic study on late-stage spreading of the Eastern Subbasin of South China Sea. Science in China (Series D). 32, 239-248.

Lin, W., Zhang, J., Li J.B., 2013. The thermal simulation of magma activities of the seamount chain after the spreading period. Marine Sciences. 37, 81-87. (in Chinese with English abstract).

Liu, J. H., 2000. The characteristics of seismic reflection waves in the middle area of the South China Sea and their significance. Acta Oceanologica Sinica. 22, 73-80 (in Chinese with English abstract). 
Meng, L., Zhang, J., 2014. The magmatic activity mechanism of the fossil spreading center in the Southwest sub-basin, South China Sea. Science in China, Series D: Earth Science. 44, 239-249.

Morgan, W.J., 1972. Plate motions and deep mantle convection. Geological Society of America Memoirs. 132, 7-22.

Nafe, J. E., Drake, C.L., 1963. Physical properties of marine sediments. In Hill, M. N. (Ed.), The Sea. Wiley-Interscience, New York. 94-815.

Niu, X.W., Ruan, A.G., Li, J.B., Minshull, T.A., Sauter, D., Wu, Z.L., Qiu, X.L., Zhao, M.H., Chen, Y.J., Singh, S., 2015. Along axis variation in crustal thickness at the ultraslow spreading Southwest Indian Ridge $\left(50^{\circ} \mathrm{E}\right)$ from a wide-angle seismic experiment. Geochem. Geophys. Geosyst,. 16, 468-485. doi:10.1002/2014GC005645.

Osler, J.C., Louden, K.E., 1995. Extinct spreading center in the Labrador Sea: Crustal structure from a two-dimensional seismic refraction velocity model. Journal of Geophysical Research. $100,2261-2278$

Pautot, G., Rangin, C., Briais, A, Tapponnier, P., Beuzart, P., Lericolais, G., Mathieu, X., Wu, J., Han, S., Li, H., Lu, Y., Zhao, J., 1986. Spreading direction in the central South China Sea. Nature. 321(8), 150-154.

Pautot, G., Rangin, C., Briais, A., Wu, J., Han, S., Li, H., Lu, Y., Zhao, J., 1990. The axial ridge of the South China Sea - A seabeam and geophysical survey. Oceanologica Acta. 13, 129-143.

Perez, A.D.C., Faustino-Eslava, D.V., Yumul Jr, G.P., Dimalanta, C.B., Tamayo Jr, R.A., Yang, T.F., Zhou, M.F., 2013. Enriched and depleted characters of the Amnay Ophiolite upper crustal section and the regionally heterogeneous nature of the South China Sea mantle. Journal of Asian Earth Sciences. 65, 107-117.

Qiu, X.L., Zhao, M.H., Ao, W., Lǘ, C.C., Hao, T.Y., 2011. OBS survey and crustal structure of the Southwest Sub-basin and Nansha Block, South China Sea. Chinese Journal of Geophys. 54, 3117-3128. doi: 10.3969/j. issn. 0001-5733.

Ruan, A.G., Niu, X.W., Qiu, X.L., Li, J.B., Wu, M.Q., 2011. A wide angle Ocean Bottom Seismometer profile across Liyue Bank, the southern margin of South China Sea. Chinese Journal of Geophysics. 54, 3139-3149. doi: 10.3969/j. issn. 0001-5733

Sandwell, D.T., Müller, R.D., Smith, W.H.F., Garcia, E., Francis, R., 2014. New global marine 
gravity model from CryoSat-2 and Jason-1 reveals buried tectonic structure. Science, 346, 65-67. doi: 10.1126/science.1258213.

Sibuet J.-C., Yeh Y.C., Lee C.S., 2016. Geodynamics of the South China Sea. Tectonophysics. In press.

Shi, X.B., Qiu, X.L., Xia, K.Y., Zhou, D. 2003. Characteristics of surface heat flow in the South China Sea. Journal of Asian Earth Sciences. 22, 265-277. doi: 10.1016/S1367-9120(03)00059-2.

Sun, Z., Zhong, Z.H., Keep, M., Zhou, D., Cai, D.S., Li, X.S., Wu, S., Jiang, J.Q., 2009. 3D analogue modeling of the South China Sea: A discussion on breakup pattern. Journal of Asian Earth Sciences. 34, 544-556.

Taylor, B., Hayes, D.E., 1980. The tectonic evolution of the South China Basin. In: Hayes, D.E. (Ed.), The Tectonic and Geologic Evolution of Southeast Asian Seas and Islands: Part 1. Geophysical Monograph Series, AGU, Washington, DC. 23, pp. 89-104.

Taylor, B., Hayes, D.E., 1983. Origin and history of the South China Sea basin. In: Hayes, D.E. (Ed.), The Tectonic and Geologic Evolution of Southeast Asian Seas and Islands: Part 2. Geophysical Monograph Series, AGU, Washington, DC. 27, pp. 23-56.

Tu, K., Flower, M.F., Carlson, R.W., Xie, G., Chen, C.Y., Zhang, M., 1992. Magmatism in the South China Basin: 1. Isotopic and trace-element evidence for an endogenous Dupal mantle component. Chemical Geology. 97, 47-63.

Wang, J., Zhao, M.H., Qiu, X.L., Sibuet, J.-C., He, E.Y., Zhang, J.Z, Tao, C.H., 2016. 3D seismic structure of the Zhenbei-Huangyan seamounts chain in the East sub-basin of the South China Sea and its mechanism of formation. Geological Journal. doi:10.1002/gj.2781

Wang, X.J., Wu, M.Q., Liang, D.H., 1984. Some geochemical characteristics of basalts from the South China Sea. Geochemica 4, 332-340 (in Chinese with English abstract).

Wang, Y.J., Han, X.Q., Luo, Z.H., Qiu, Y.Z., Ding, W.W., Li, J.B., Gao, S.T., Chen, R.H., 2009. Late Miocene magmatism and evolution of Zhenbei-Huangyan Seamount in the South China Sea: Evidence from petrochemistry and chronology. Acta Oceanologica Sinica. 93-102 (in Chinese with English abstract).

Wessel, P., Smith, W.H., 1995. New version of Generic Mapping Tools released. Eos, Trans. Am. Geophys. Union 76(33), 329. 
White, R.S., Mckenzie, D., O'Nions, R.K., 1992. Oceanic crustal thickness from seismic measurements and rare earth element inversions. Journal of Geophysical Research. 97, 19683-19715.

Yan, Q.S., Shi, X.F., Wang, K.S., Bu, W.R., Xiao, L., 2008. Major element, trace element, Sr, Nd, $\mathrm{Pb}$ isotopic studies of Cenozoic basalts from the South China Sea. Science in China Series D: Earth Science. 51, 550-566.

Yao, B.C., 1996. Tectonic evolution of the South China Sea in Cenozoic. Marine Geology \& Quaternary Geology. 16, 1-13 (in Chinese with English abstract).

Yao, B.C., Wang, G.Y., 1983. Crustal structure of the South China Sea Basin. Science in China Series B. 26, 649-661 (in Chinese with English abstract).

Yao, C.L., Hao, T.Y., Guang, Z.N., Zhang, L.W., 2003. High-speed computation and efficient storage in 3-D gravity and magnetic inversion based on genetic algorithms. Chinese Journal of Geophysics. 46, 252-258.

Zelt, C.A., 1999. Modelling strategies and model assessment for wide angel seismic travel-time. Geophysical Journal International. 139, 183-204.

Zelt, C.A., Smith, R.B., 1992. Seismic traveltime inversion for 2-D crustal velocity structure. Geophysical Journal International. 108, 16-34.

Zhang, L., Zhao, M.H., Wang, J., He, E.Y., 2013. Correction of OBS position and recent advances of 3D seismic exploration in the central sub-basin of South China Sea. Earth Science Journal of China University of Geosciences. 38, 33-42 (in Chinese with English abstract). 
Fig. 1. (a) Bathymetric map of the South China Sea with 200, 1000 and 3000-m isobaths. NWSB, ESB, SWSB are the Northwest, East and Southwest Sub-basins, respectively. (b) Shaded-relief image of the portion of South China Sea identified as a red box in a). The red broken lines are the boundaries of the oceanic domain formed during the last spreading phase characterized by $\mathrm{N} 055^{\circ}$ rift trends, the solid yellow line represents the potential location of the extinct spreading ridge (ESR), the dashed yellow lines represent the transform fault located in the Zhongnan faults zone, between the ESB and SWSB (Sibuet et al., 2016). A ridge jump (Li et al. 2014) is underlined by the black arrow between the orange dashed and solid lines. The magnetic anomalies (white thin lines), the deep-tow magnetic survey profile da13 (thin red line) and multichannel seismic profiles SO49-17, 973SCSIO1 and N3 (thin yellow lines) are from Li et al. $(2014 ; 2015)$. Orange line with triangles indicates the Manila Trench and the yellow star marks the location of Huangyan Island. Red dots indicate Sites U1431, U1433, U1434 drilled during the IODP 349 expedition (Expedition 349 Scientists, 2014).

Fig. 2. Location of Profile G8G0 in the East Sub-basin. Positions of the nine OBSs and the air gun shooting track with 448 shots are shown with OBS numbers and a yellow line, respectively. The black arrow is the direction of shooting. The pink star is the location of IODP hole U1431. The pink solid line marks the location of the deep-tow magnetic survey profile da13 (Li et al., 2014). Red dots show the locations of dredged samples (Wang et al., 1984; Wang et al., 2009). White narrow lines mark the $\mathrm{C} 5 \mathrm{Cr}$ and $\mathrm{C} 5 \mathrm{~B}$ magnetic lineations (Li et al., 2014). The ESR (thick yellow line) and the northern boundary of the $\mathrm{N} 055^{\circ}$ rift trends (thick red dashed line) are from Sibuet et al. (2016).

Fig. 3. Ray tracing and travel times simulation for OBS02 along Profile G8G0. (a) Seismic record section with the reduced velocity of $6.0 \mathrm{~km} / \mathrm{s}$. (b) Observed travel time (broken color lines) with associated uncertainties shown as vertical bars, and calculated travel time curves (black thin lines) from the final model. (c) Calculated 
final model and ray-tracing simulation. The different ray colors correspond to the different travel time colors in (b).

Fig. 4. Ray tracing and travel times simulation for OBS05 along Profile G8G0. Other legends are the same as in Fig. 3.

Fig. 5. Ray tracing and travel times simulation for OBS06 along Profile G8G0. Other legends are the same as in Fig. 3.

Fig. 6. Ray tracing and travel times simulation for OBS09 along Profile G8G0. Le Other legends are the same as in Fig. 3.

Fig. 7. (a) Single-channel seismic profile G8G0. Thin blue lines underline the seafloor and the basement. Purple, green, orange thick lines show the seismic sequence boundaries of middle Miocene/late Miocene (Tmm), late Miocene/Pliocene (Tmp), and Pliocene/Pleistocene (Tpp), respectively (Li et al., 2015). (b) Raw single-channel seismic section G8G0. (c) Volcano-clastic sediments result from the erosion of the adjacent seamount formed during the post-spreading phase (Profile SO49-17) (Li et al., 2015). (d) Volcano-clastic sediments resulting from the erosion of the adjacent seamounts formed during the post-spreading phase (Profile N3 located in the Southwest Sub-basin) (Li et al., 2015). TWTT $=$ two way travel time, $\mathrm{CDP}=$ common depth point.

Fig. 8. (a) Final P-wave crustal structure with ray coverage obtained with the RayInvr software (Zelt, 1992). Yellow circles are OBSs locations along the G8G0 profile. ESR, extinct spreading ridge. The three triangles with different colors in (a) correspond to the three 1-D velocity-depth profiles in Fig. 10. The thick white segments indicate where the Moho interface is constrained by PmP arrivals. (b) Distribution of ray densities on a $0.25 \mathrm{~km} \times 0.125 \mathrm{~km}$ grid corresponding to the velocity model in (a). (c) Velocity perturbation model derived by subtracting the average 1-D velocity model 
from the final model (a).

Fig. 9. (a) Final velocity model derived from TOMO2D software (Korenaga et al.; 2000) with a floating Moho interface. (b) Standard deviation stands for velocities uncertainty and Moho uncertainty. (c) Derivative weight sum for the final velocity model. Other legends are the same as in Fig. 8.

Fig. 10. 1-D velocity-depth profiles extracted from the final velocity model at distances of 17, 52 and $90 \mathrm{~km}$ corresponding to the different color triangles in Fig. 8a. The gray area shows the range of typical velocities for the Atlantic oceanic crust (0-127 Ma) after White et al. (1992). 1-D velocity profiles from the Labrador Sea (Delescluse et al., 2015) and from Aegir rift (Brandsdóttir et al., 2015) for comparison.

Fig. 11. Free-air gravity forward modeling along the G8G0 profile. Best-fitting density model with densities in $\mathrm{g} / \mathrm{cm}^{3}$. Other legends are the same as in Fig. 8 .

Fig. 12. Geological model. The x-axis is based on the velocity model of the G8G0 profile, and the y-axis is inferred from the bathymetric data. Thick yellow line is the ESR and the red dashed line is the northern boundary of $\mathrm{N} 055^{\circ}$ seafloor spreading lineaments in the East Sub-basin. The second profile just makes up 3D images for reference. 


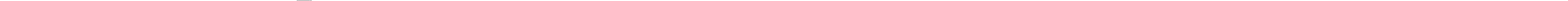



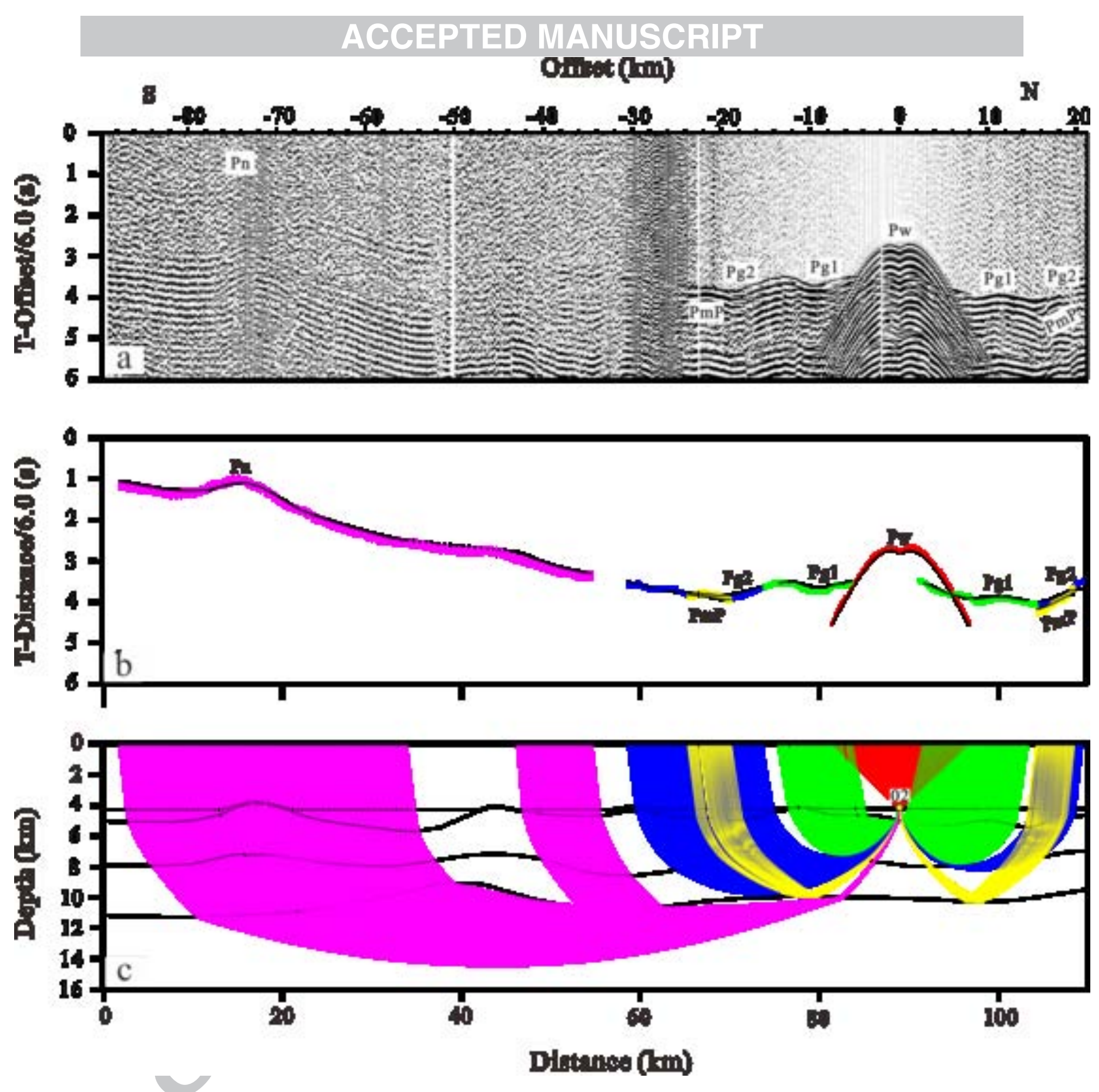

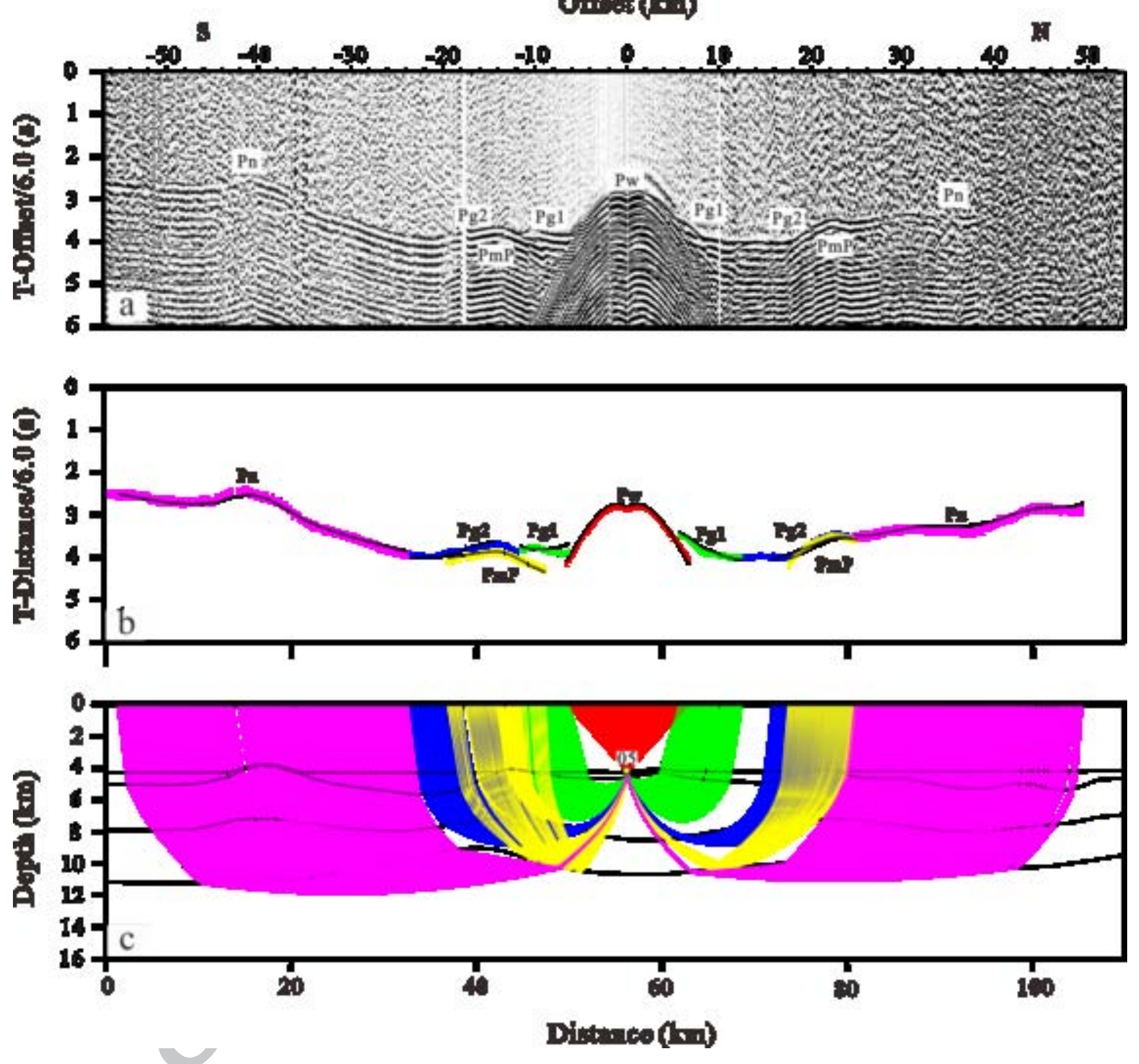

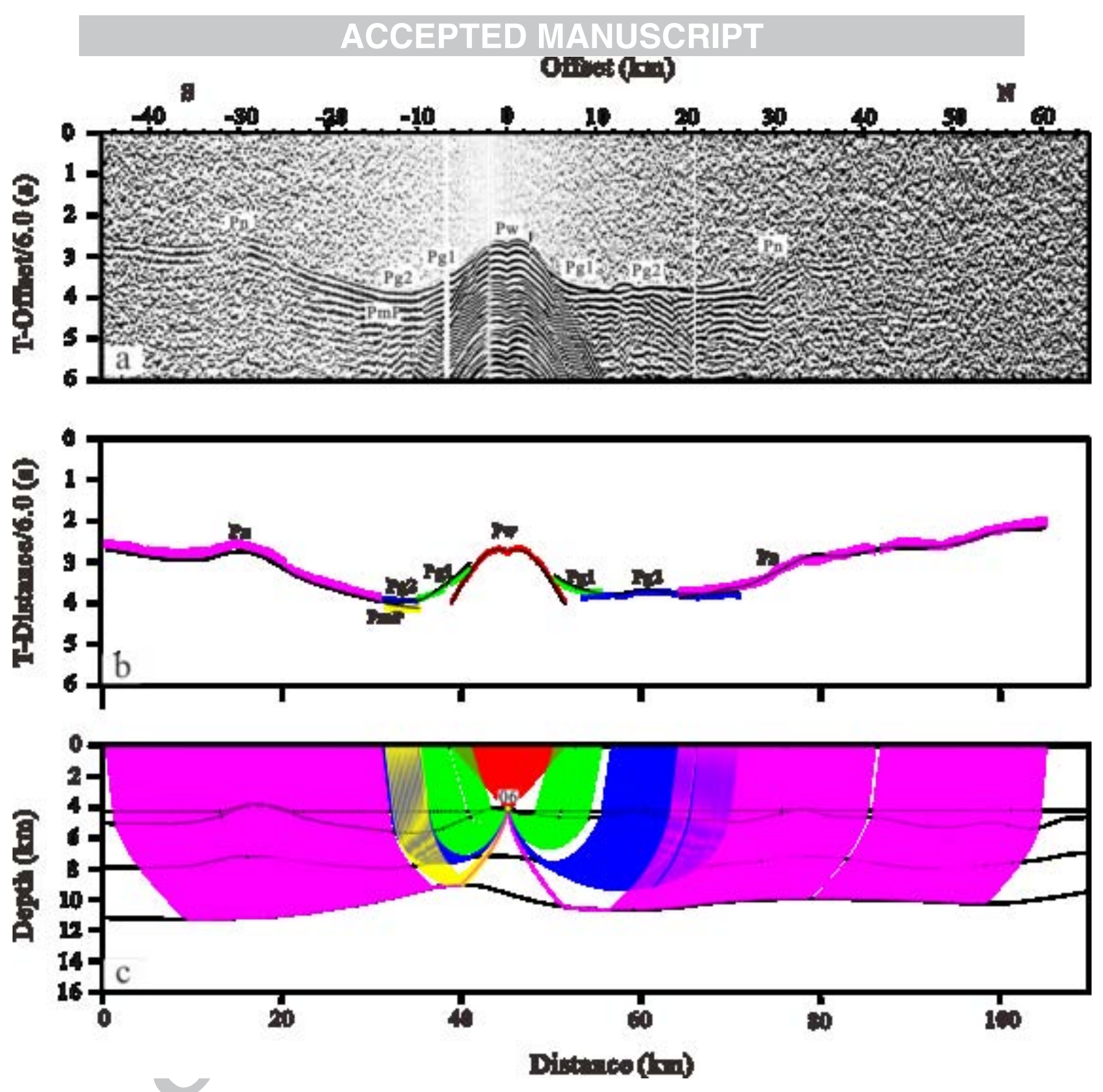

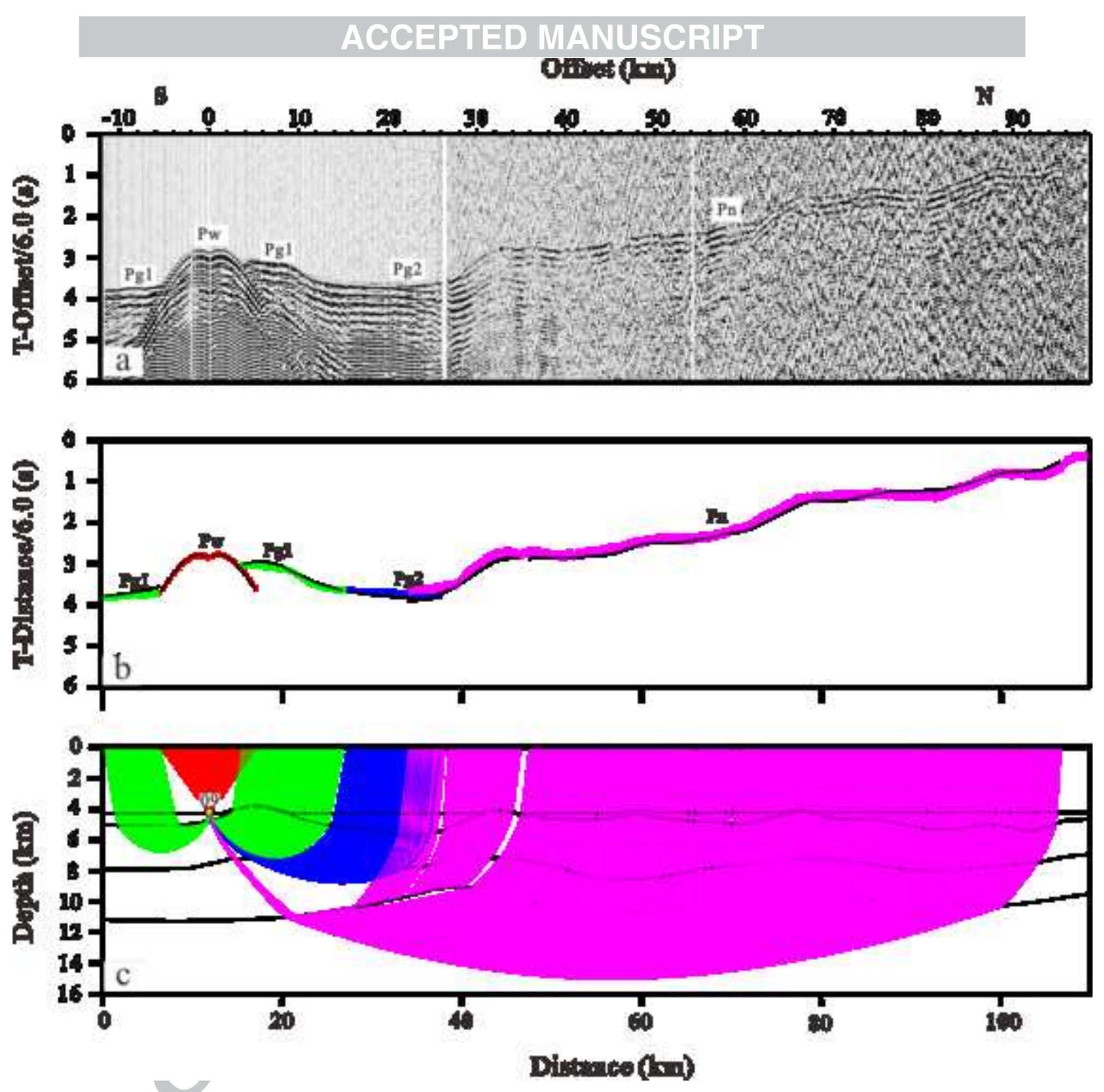

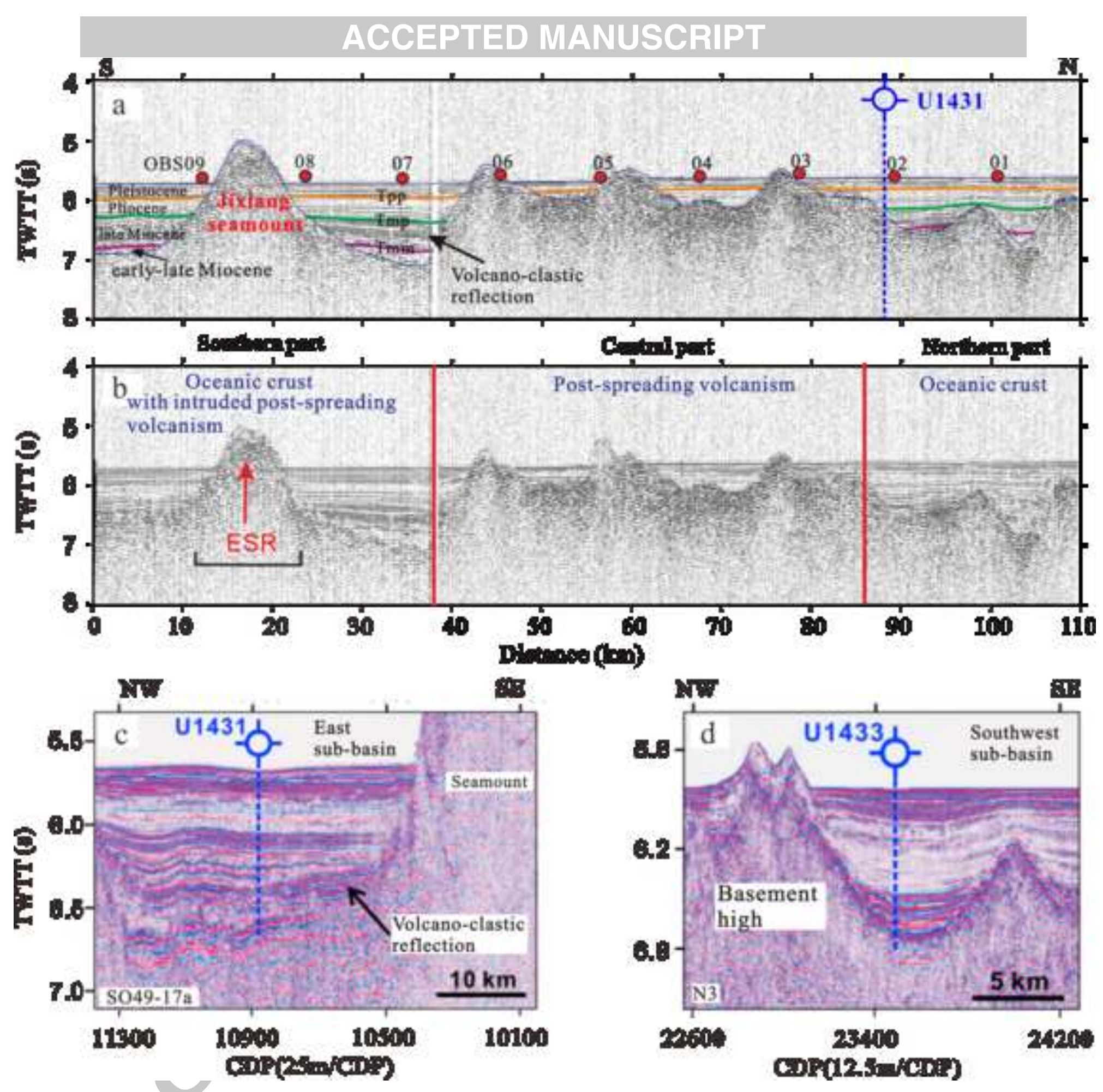

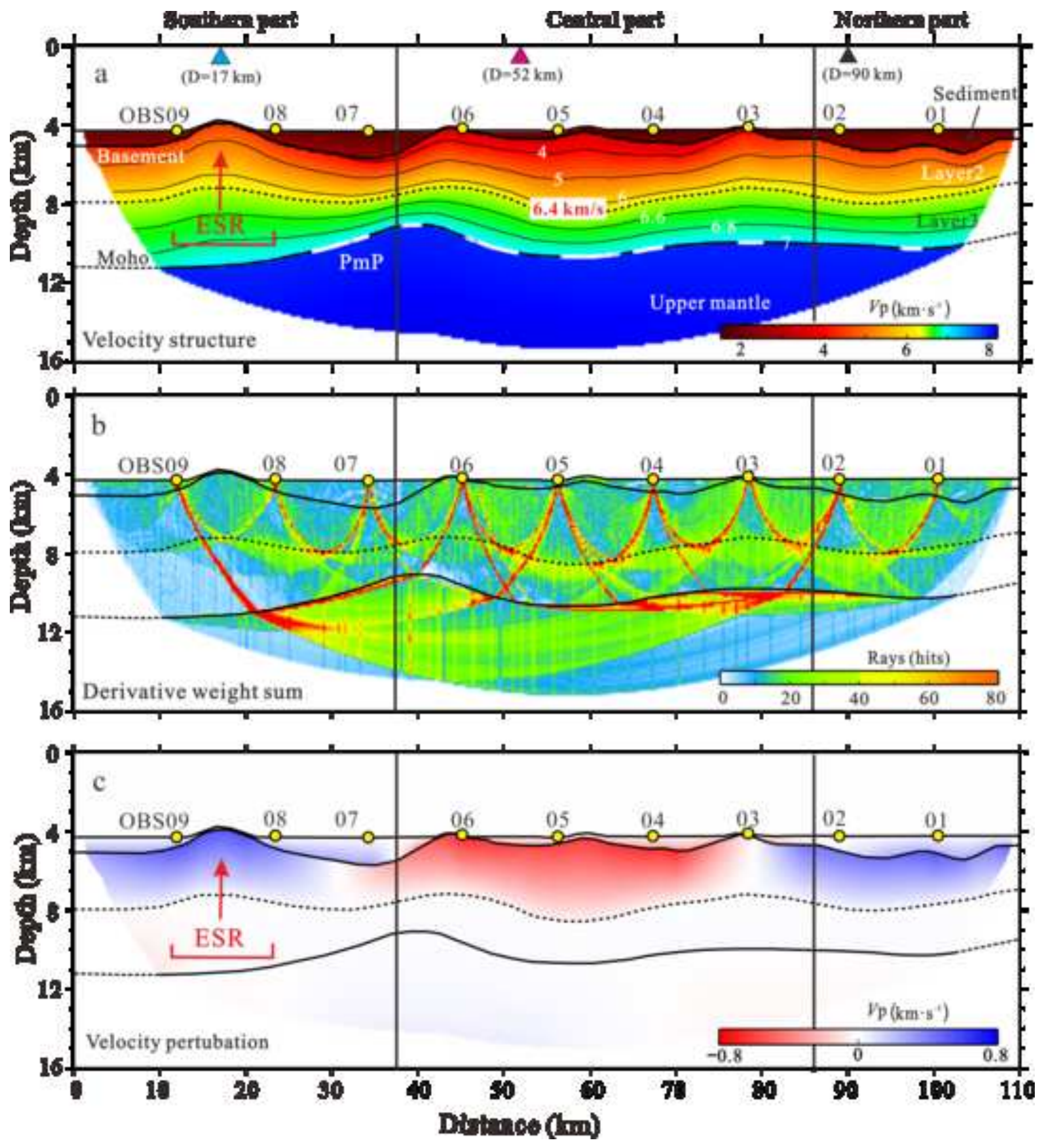


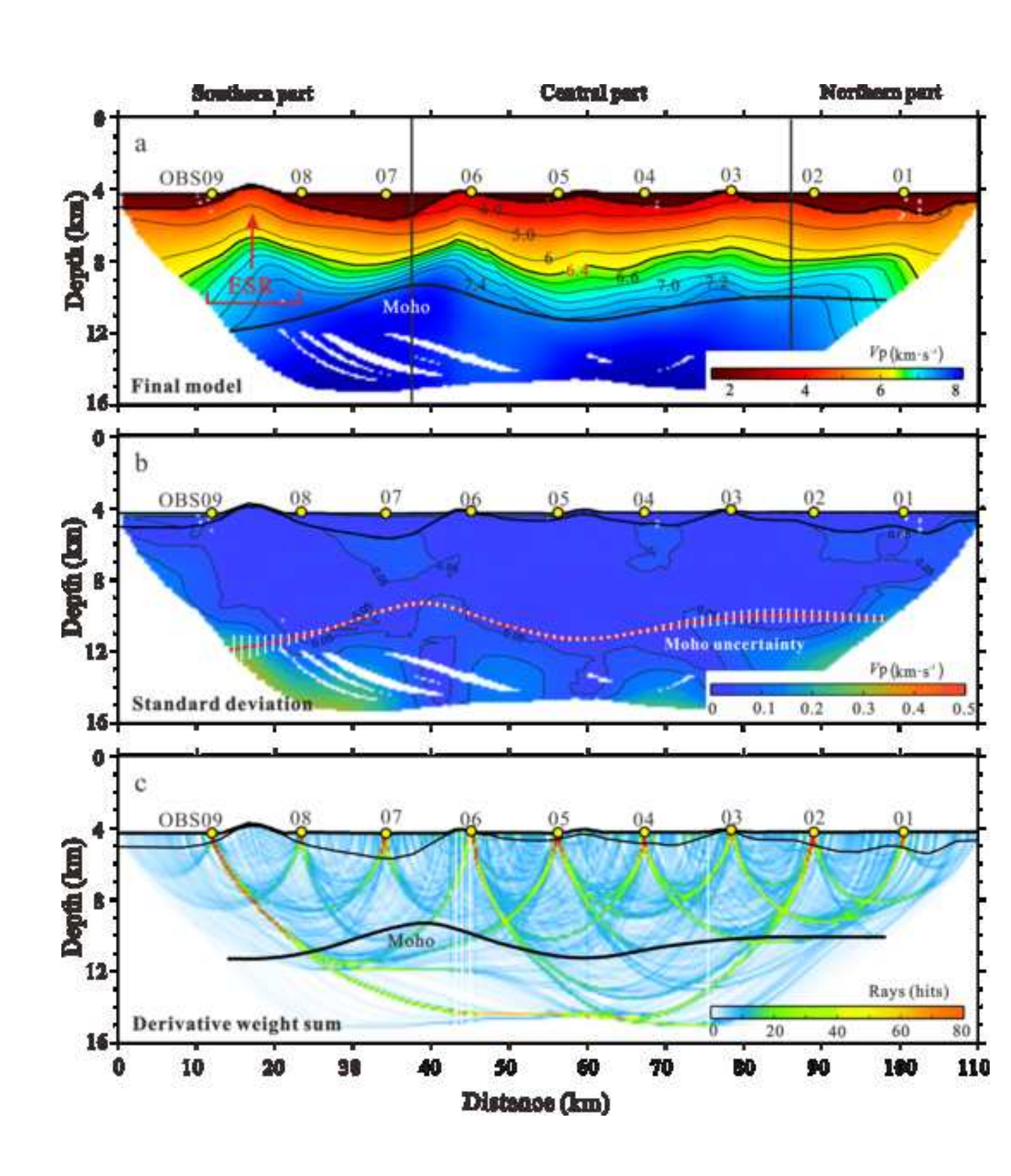

\section{ACCEPTED MANUSCRIPT}
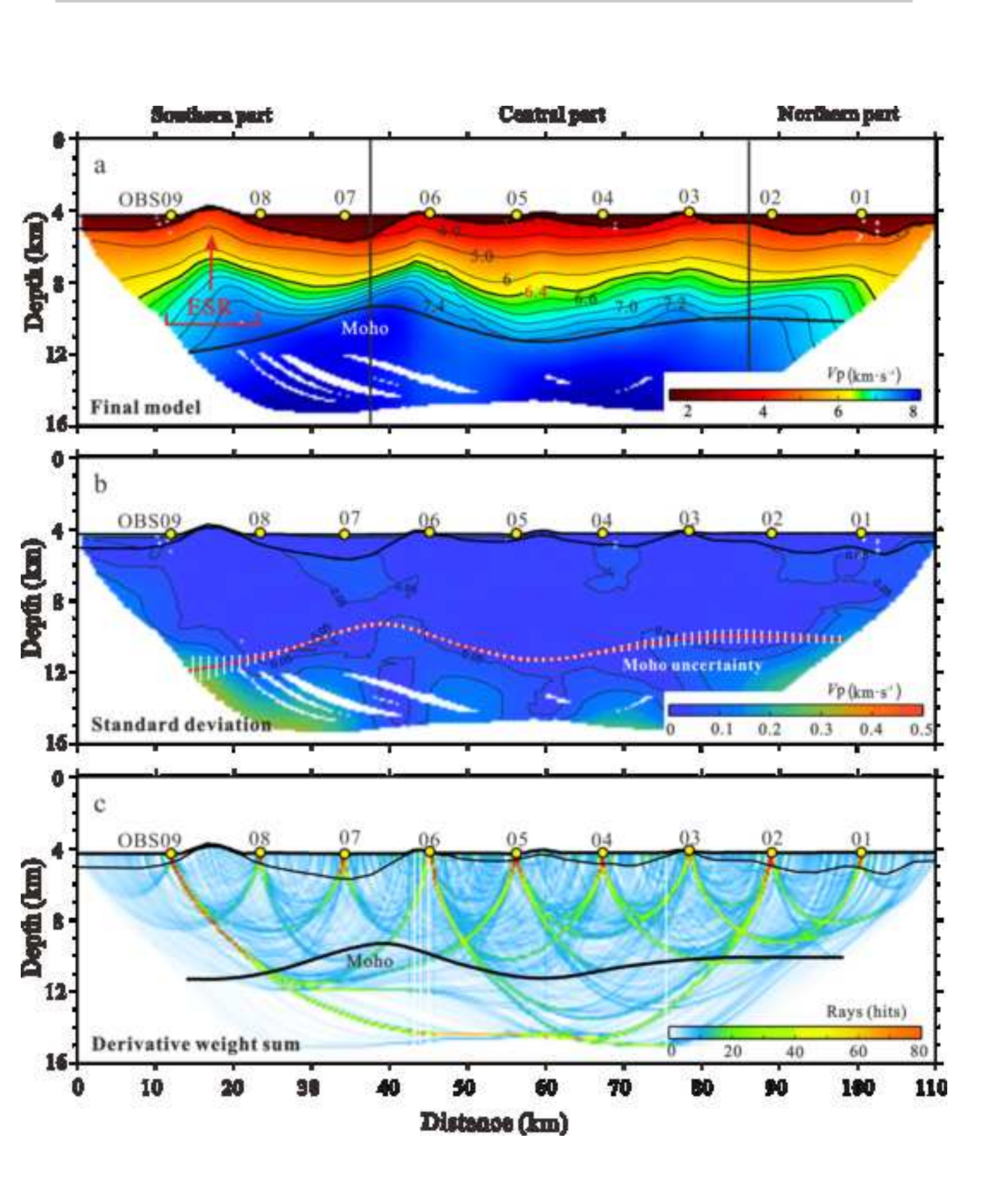


\section{ACCEPTED MANUSCRIPT}

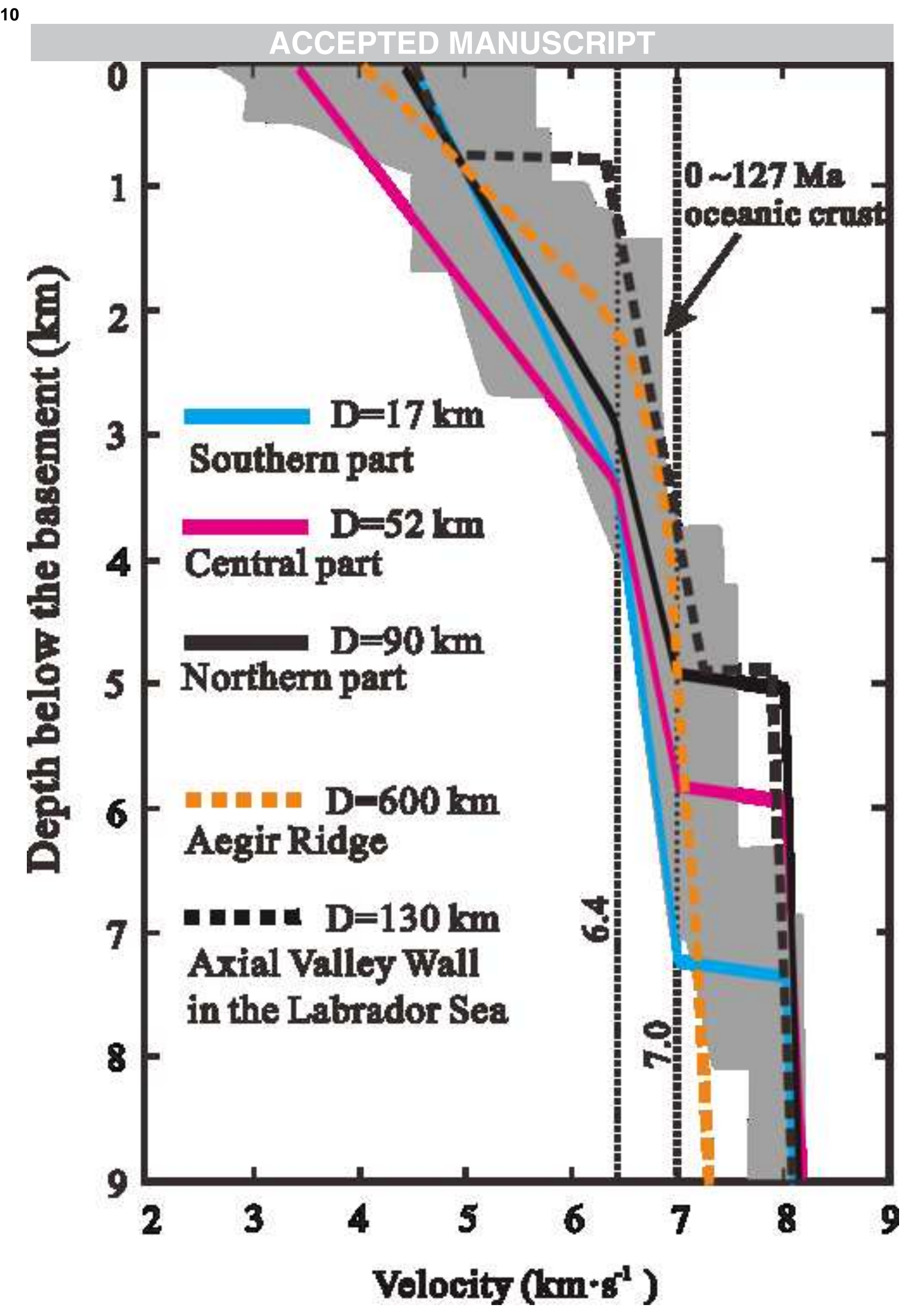

Figure 10 

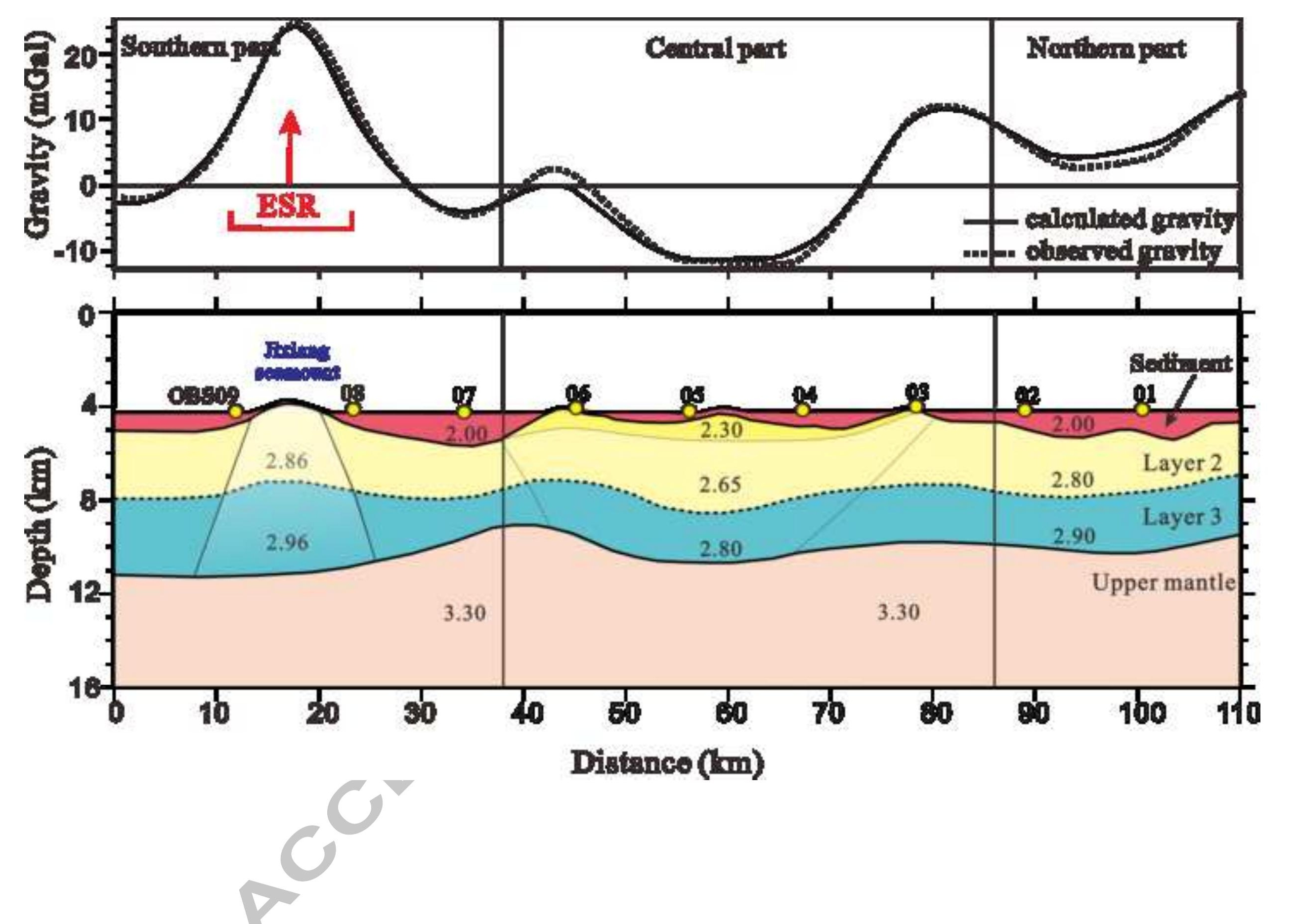

\section{ACCEPTED MANUSCRIPT}

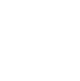

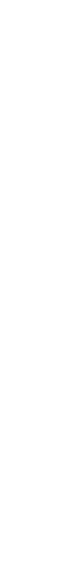

Distanco (1m)

.




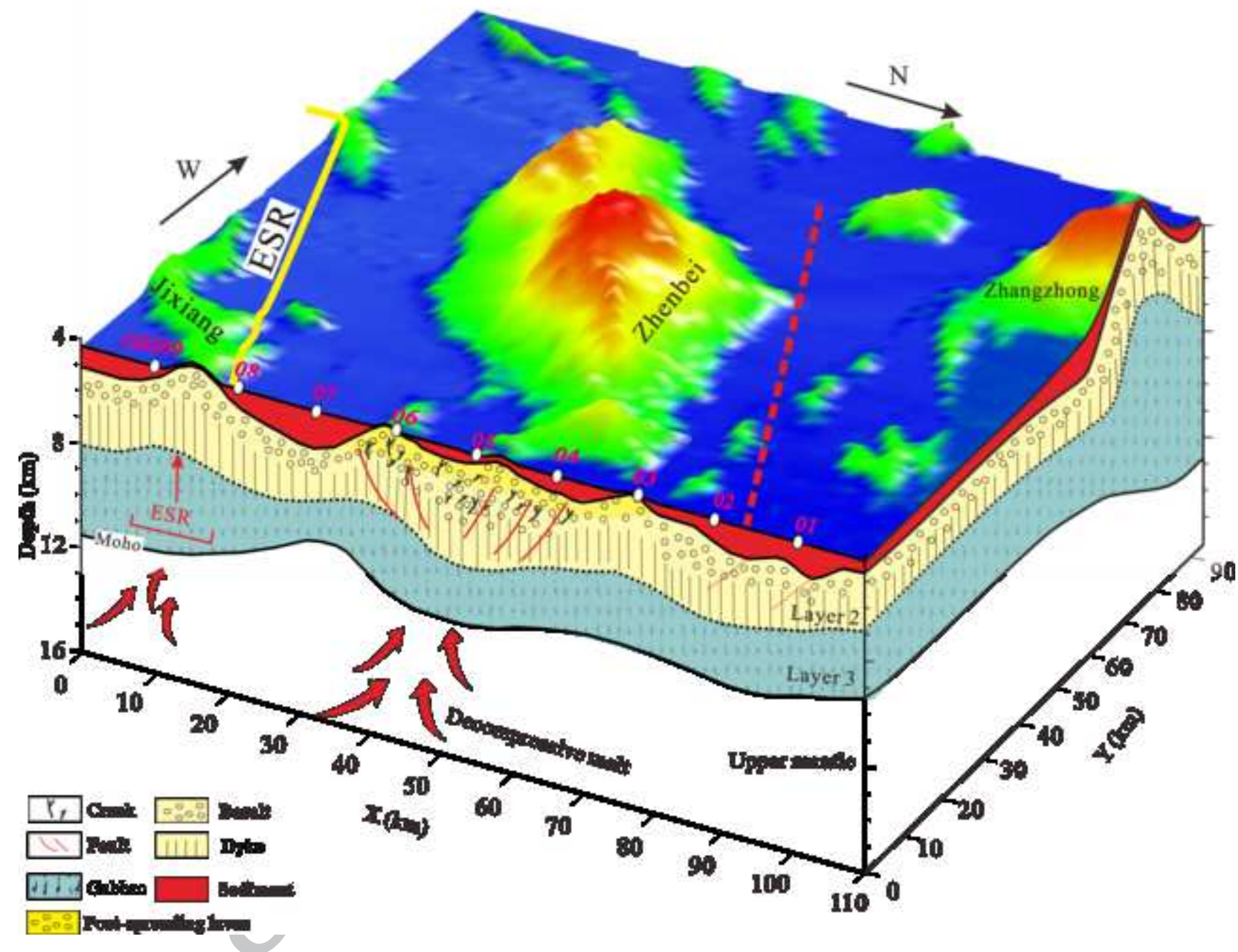


Table 1. Ray-tracing and travel time simulation results of the final model

\begin{tabular}{cccc}
\hline Phases & Number of picks & RMS $(\mathrm{s})$ & Normalized $\chi^{2}$ \\
\hline Pg1 & 500 & 0.071 & 2.023 \\
Pg2 & 713 & 0.055 & 1.204 \\
PmP & 251 & 0.066 & 0.890 \\
Pn & 1039 & 0.091 & 1.029 \\
Total & 2503 & 0.076 & 1.262 \\
\hline
\end{tabular}

Table 2. Seismic velocities of the uppermost oceanic crust derived from deep seismic wide-angle reflection and

\begin{tabular}{|c|c|c|c|c|c|}
\hline Line number & Location & $\begin{array}{l}\text { Magnetic } \\
\text { anomalies }\end{array}$ & $\begin{array}{l}\text { Age of ocean } \\
\text { crust (Ma) }\end{array}$ & $\begin{array}{l}\text { rmost velocity } \\
(\mathrm{km} / \mathrm{s})\end{array}$ & References \\
\hline OBS973-1 & SWSB & $\mathrm{C} 5 \mathrm{e}-\mathrm{C} 5 \mathrm{c}$ & $19-16$ & $4.5-5.5$ & Qiu et al., 2011 \\
\hline OBS2006-1 & NWSB & $\mathrm{C} 11-\mathrm{C} 10$ & $30-28.7$ & 5.4 & Wu et al., 2012 \\
\hline OBS2006-2 & NWSB & & $30-28.7$ & $5.5-6.0$ & Ao et al., 2012 \\
\hline OBS2006-1 & CSB & & $25.5-23.5$ & 6.3 & Wu et al., 2012 \\
\hline OBS973-2 & CSB & C11-C8 & $30-25.5$ & 5.9 & Ruan et al., 2011 \\
\hline
\end{tabular}

